\title{
WAVELET DECOMPOSITION-BASED ANALYSIS OF MISMATCH NEGATIVITY ELICITED BY A MULTI-FEATURE PARADIGM
}

\author{
Received 22.10.2013
}

In this study, event-related potentials (ERPs) collected from normally hearing subjects and elicited by a multi-feature paradigm were investigated, and mismatch negativity (MMN) was detected. Standard stimuli and five types of deviant stimuli were presented in a specified sequence, while EEG data were recorded digitally at a $1024 \mathrm{sec}^{-1}$ sampling rate. Two wavelet analyses were compared with a traditional difference-wave (DW) method. The Reverse biorthogonal wavelet with an order of 6.8 and the quadratic B-Spline wavelet were applied for seven-level decomposition. The sixth-level approximation coefficients were appropriate for extracting the MMN from the averaged trace. The results obtained showed that wavelet decomposition (WLD) methods extract MMN as well as a band-pass digital filter (DF). The differences of the MMN peak latency between deviant types elicited by B-Spline WLD were more significant than those extracted by the DW, DF, or Reverse biorthogonal WLD. Also, wavelet coefficients of the delta-theta range indicated good discrimination between some combinations of the deviant types.

KEYWORDS: event-related potentials (ERPs), mismatch negativity (MMN), differencewave (DW), band-pass digital filter (DF), wavelet decomposition (WLD) techniques.

\section{INTRODUCTION}

Evoked potentials (EPs) or, more generally, eventrelated potentials (ERPs) are defined as changes in the electroencephalogram (EEG) related to certain events (external stimulation or internal processes in the CNS). Recently, mismatch negativity (MMN) studies of the central auditory function have become very popular [1]. The MMN detection opened an unprecedented window to the central auditory processing. The MMN, a changespecific component of the auditory ERP, is elicited by any discriminable change in auditory stimulation [2]. The MMN response is seen as a negative displacement recorded, in particular from frontocentral and central scalp sites relative to a mastoid or nose reference [3].

The new multi-feature paradigm was proposed by Näätänen et al. [4] allowing one to obtain MMNs for

\footnotetext{
${ }^{1}$ Electronics Group, Faculty of Engineering, Shahed University, Tehran, Iran ${ }^{2}$ Department of Otorhinolaryngology, Hannover Medical University (MHH), Hannover, Germany

${ }^{3}$ ENT and Head and Neck Research Center, Tehran University of Medical Sciences (TUMS), Tehran, Iran

${ }^{4}$ Biomedical Engineering Faculty, Amirkabir University of Technology, Tehran, Iran

Correspondence should be addressed to M. Najafi-Koopaie (e-mail: mj.najafi@shahed.ac.ir, mojtabanajafi1366@gmail.com).
}

several auditory attributes within a short time. During the experiment, standard stimuli and five different types of deviant stimuli were presented. Figure 2 displays features of each stimulus in summary.

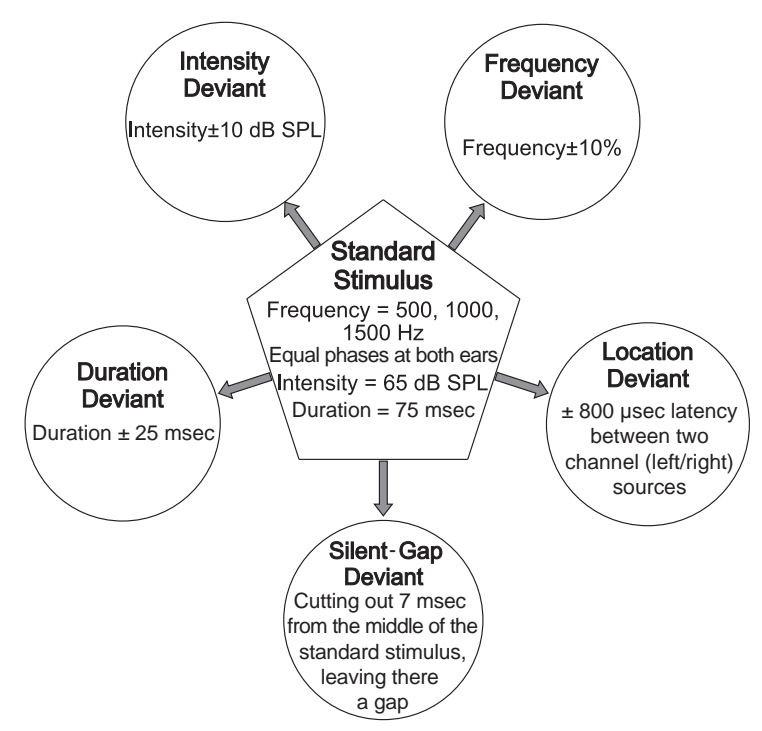

F i g. 2. Specifications of the standard and five types of deviant stimuli in summary.

Р и с. 2. Стандартні стимули та девіантні стимули п'яти типів. 
Data extraction is crucially important in $\mathrm{MMN}$ studies. Prevalently, after artifact rejection, recordings belonging to each type of stimulus are averaged to obtain the ERP waveform. Responses to standard stimuli are typically subtracted from the ERPs elicited by infrequently presented deviant stimuli. The resulting wave is called the difference wave (DW), which indicates the MMN [5]. The peak amplitude and peak latency of MMN are usually measured from the DW. This is the most typical processing used for MMN detection.

Generally, the signal processing techniques to extract MMN are divided into two categories, single-channel and multi-channel procedures. Some methods, such as difference-wave (DW), digital filters (DFs) $[6,7]$, and wavelet decomposition (WLD [8] can be applied to one channel, and these are the single-channel procedures. Other methods, such as component analysis $[9,10]$ and matrix factorization [11], need more than one channel and are categorized as multi-channel procedures.

The idea of using the adaptive filtering technique for the analyzing of EPs was first proposed by Orfanidis [12] and Thakor [13] and, later on, was investigated by other authors [14-16]. Researchers employed time-frequency analysis to gain understanding of mass electrical activity of the brain. The wavelet transform has been applied to a few bioelectric signals. Thakor et al. [17] used a waveletbased method for the analysis of ECG data, and Schiff et al. [18] used this approach for EEG.

Wavelet filters were especially designed for nonstationary signals; they utilize both time and frequency information related to a signal. WLD techniques factorize the signal into several levels with a particular wavelet at first, and then coefficients of the selected levels can be used for reconstruction or comparison [19]. Each level of decomposition matches to a certain frequency band, although frequency bands of neighboring levels may overlap each other around the cut-off frequencies. Since the selected wavelet for decomposition and reconstruction may be correlated with the desired signal, overlapping signals can be separated by a DF.

In our study, five types of MMN were obtained using five different types of deviant stimuli presented in a special sequence. EEG signals of young people were recorded, and MMNs were analyzed with quadratic B-Spline WLD. To validate the effectiveness of the proposed methods, the results were compared with the average-based DW (calculated by subtracting the standard response from the deviant response), a DF technique, and a Reverse biorthogonal WLD with an order of $6.8[20]$.

\section{METHODS}

Subjects. The group of participants consisted of 43 healthy normally hearing volunteers, 21 men and 22 women. They were between 20 to 24 years old, with no history of auditory disorders, and most of them were university students.

Stimuli. In this study, MMNs were obtained using the new paradigm proposed by Näätänen et al. [4], with a little change in the number of stimuli to shrink the time of recording. This paradigm makes it possible to obtain five types of MMN in a considerably shorter recording time compared with the traditional oddball conditions. In the new paradigm, each deviant is presented after a standard stimulus, meaning that the deviants occur with the probability of 0.5 relative to the standards $\left(\mathrm{P}_{\mathrm{Std}}=0.5, \mathrm{P}_{\mathrm{Dev}}=0.5 / 5=0.1\right)$. Standard stimuli were composed of three sinusoidal tones of 500,1000 , and $1500 \mathrm{~Hz}$ with a total duration of $75 \mathrm{msec}$ including $5-\mathrm{msec}$ rise and 5-msec fall time. The intensity of the second and third tones sequentially was 3 and $6 \mathrm{~dB}$ lower than the first tone, respectively. The stimuli were presented binaurally via ER-3A insert earphones with an intensity level of $65 \mathrm{~dB}$ SPL and equal phase in both ears.

The deviant stimuli were generated differently from the standards in five categories. These differences were in the frequency, intensity, duration, perceived soundsource location, and a gap in the middle of the tone signal. Frequency, intensity, and location deviants were in two modes. A half of the frequency deviant tones were $10 \%$ higher $(550,1100,1650 \mathrm{~Hz})$, while another half were $10 \%$ lower $(450,900,1350 \mathrm{~Hz})$ than the standard. A half of the intensity deviants were $10 \mathrm{~dB}$ lower and another half were $10 \mathrm{~dB}$ higher than the standard. Deviants of location were generated based on a change in the location of a perceived sound source. An interaural time difference of $800 \mu \mathrm{sec}$ was applied for half of the deviants to the right channel and another half to the left channel. The duration deviant was shorter than in duration $(5-\mathrm{msec}$ rise, $15-\mathrm{msec}$ flat, and 5-msec fall times). The silent gap deviant consisted of a 7-msec silent gap (including 1-msec rise and 1-msec fall times) in the middle of the standard stimulus. Fig. 1 shows the waveforms of a standard stimulus, duration deviant, and silent gap deviant. Each deviant differed from the standard only in one feature. Features of the standard and deviants stimuli are shown in Fig. 2 in summary. 

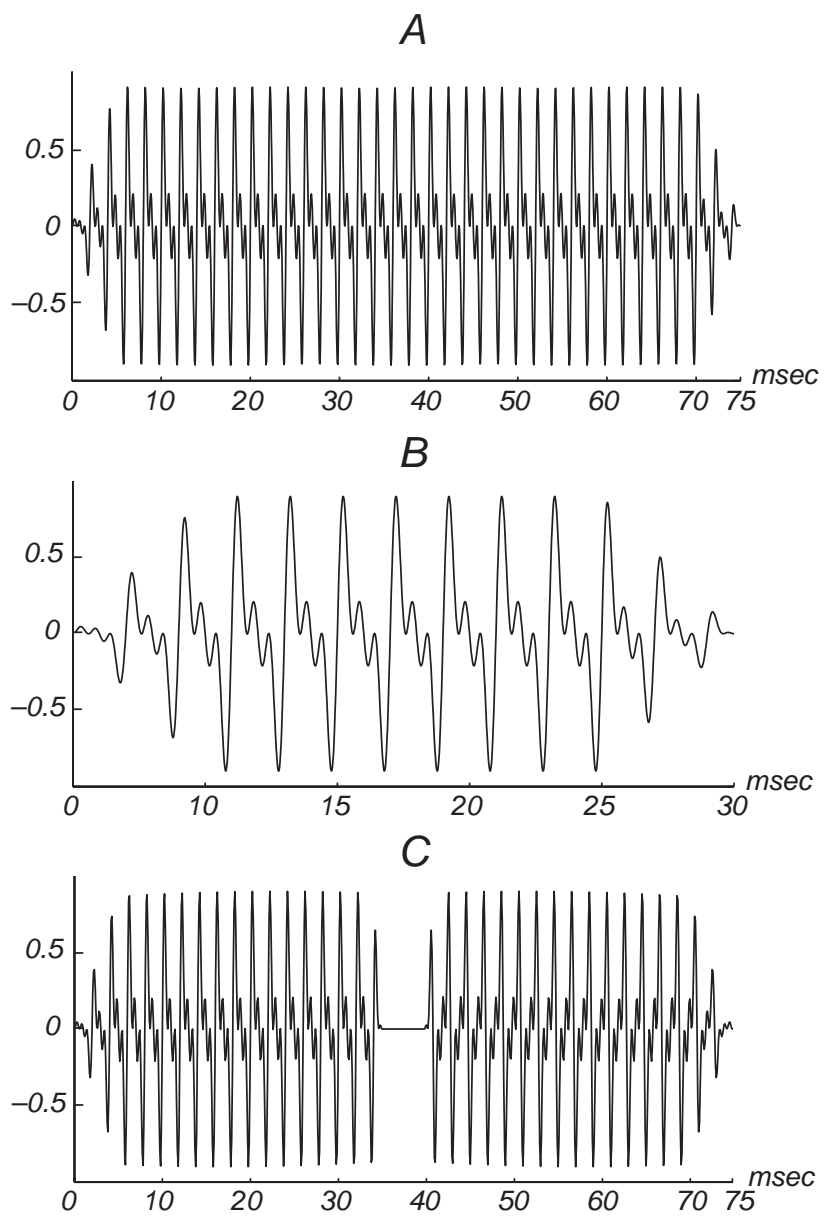

F i g. 1. Waveforms of a standard stimulus (A), duration deviant (B), and silent-gap deviant (C) generated by MATLAB software ${ }^{\circledR}$.

Р и с. 1. Форми стандартного стимулу $(A)$, девіанта щодо тривалості $(B)$ та девіанта 3 „вікном мовчання” $(C)$, генерованих 3 використанням MATLAB.

The stimuli were presented in two 5-min-long blocks with a $500 \mathrm{msec}$ onset asynchrony. In each block, the first 15 stimulus were standards, and the deviants were presented pseudo-randomly within the stimuli. So in an array of five deviants, each deviant was presented once, and two similar types of deviants never followed each other (Fig. 3). A total of 1,230 stimuli was presented within the total recording time (about $10 \mathrm{~min}$ ) for the five types of deviants. Stimuli were presented via Presentation ${ }^{\circledR}$ software (version 0.71 , Neurobehavioral Systems ${ }^{\odot}$, USA). This software is a specialized stimulus delivery and experimental control program for neuroscientific research purposes.

Procedure. EEG was recorded in electromagneticand sound-proof chamber. Participants were seated on a comfortable chair, and their head, neck, and

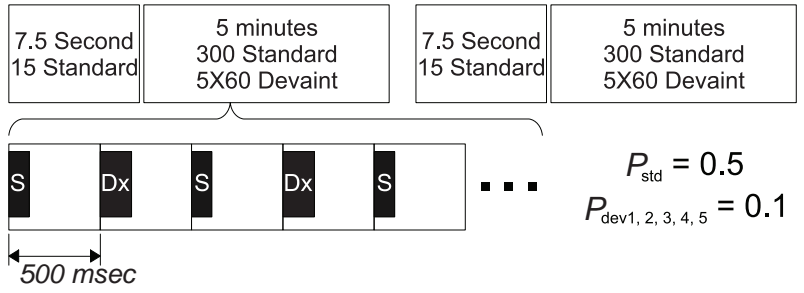

F i g. 3. Sequence of presentation of the stimuli. $S$ indicates a standard stimulus, and Dx indicates different deviant types.

Р и с. 3. Послідовність пред'явлення стимулів.

back were supported with pillows to reduce muscle contractions. They, after setting an EEG cap on the scalp, were instructed to be relaxed, ignore the auditory stimuli, and stay awake. A subtitled silent movie was played on a front monitor, to maintain alertness and to help participants to pay no attention to the stimuli during the experiment. The EEG recording session, including preparation and recording per se, lasted about $30 \mathrm{~min}$.

EEG Recording. Sixty-four-channel BRAIN QUICK LTM (Micromed, Italy) was used for recording electrical brain activities. Twenty-seven EEG channels were used. $\mathrm{Ag}-\mathrm{AgCl}$ electrodes were filled with Electro-Gel and placed on 27 selected scalp sites (FP1, FPz, FP2, F7, F3, Fz, F4, F8, FT7, $\mathrm{FC} 3, \mathrm{FCz}, \mathrm{FC} 4, \mathrm{FT} 8, \mathrm{~T} 7, \mathrm{C} 3, \mathrm{Cz}, \mathrm{C} 4, \mathrm{~T} 8, \mathrm{TP} 7$, $\mathrm{CP} 3, \mathrm{CPz}, \mathrm{CP} 4, \mathrm{TP} 8, \mathrm{P} 3, \mathrm{Pz}, \mathrm{P} 4$, and $\mathrm{POz}$ ) and mastoids (M1 and M2), according to the international 10-20 system. The potentials were referred to the nose tip. Electrooculogram activity (EOG) was recorded by placing electrodes below the left eye and at its outer canthus. Impedances during recording did not exceed $5 \mathrm{k} \Omega$. EEG signals were digitized with the sampling rate of $1024 \mathrm{sec}^{-1}$ and filtered by an online band-pass filter in the $0.001-100 \mathrm{~Hz}$ range. In addition, a customdesigned microcontroller device received digital events from Neurobehavioral presentation software and reformed it to compatible trigger signals to mark events on the computerized EEG record.

EEG Data Preprocessing. The EEG data were analyzed off-line using MATLAB ${ }^{\circledR}$ 7.1. At first, these data were filtered by an off-line band-pass digital filter in the $0.5-40 \mathrm{~Hz}$ range. Then, epochs were extracted from the continuous data according to a trigger signal 
that was generated by microcontroller device. All data were baseline-corrected by $100 \mathrm{msec}$ pre-stimulus. The EEG data were checked for blink, ECG, and other muscular artifacts by visual inspection. Epochs with artifacts were rejected from subsequent processing. In addition, epochs where the amplitude exceed $80 \mu \mathrm{V}$ were automatically rejected. The mean number of trials (after artifact rejection) per subject was 1027 . Finally, epochs of the standards and all type of deviants were averaged within $100 \mathrm{msec}$ pre- stimulus to $380 \mathrm{msec}$ post-stimulus segments separately. The first 15 standards of each block were rejected from averaging.

EEG data analysis. In several researches, various frequency bands were used to filter out interference from an averaged MMN trace. Kalyakin et al. [21] reported that the optimum frequency band of MMN of children was $2.0-8.8 \mathrm{~Hz}$ for the uninterrupted sound paradigm; Stefanics et al. [7] used two frequency bands (2.5-16 and $1.5-16 \mathrm{~Hz}$ ) to obtain the MMN of neonates. Picton et al. [22] reported that most MMN energy was concentrated within the $2-5 \mathrm{~Hz}$ frequency range. Tervaniemi et al. [23] used a $2-12 \mathrm{~Hz}$ band-pass digital filter for analyzing the peak amplitude and latency of MMN.

The wavelet transform gives a time frequency representation of a signal that is defined as the convolution between the signal $x(t)$ and the wavelet function $\psi_{\mathrm{a}, \mathrm{b}}(t)$

$$
W_{\Psi} X(a, b)=\left\langle x(t) \mid \Psi_{a, b}(t)\right\rangle,
$$

where $\psi_{\mathrm{a}, \mathrm{b}}(t)$ are dilated and shifted versions of a unique wavelet function $\psi(t)$

$$
\psi_{a, b}(t)=|a|^{-1 / 2} \psi\left(\frac{t-b}{a}\right) .
$$

Here, $a$ and $b$ are the scale and translation parameters, respectively [24]. Discrete wavelet transform (DWT) applies to discrete time signals $x[n]$. It achieves a multiresolution decomposition of $x[n]$ on $I$ octaves labeled by $i=1, \ldots, I$ and given by

$$
x[n]=\sum_{i=1}^{\infty} \sum_{k \in Z} a_{i, k} g_{i}\left[n-2^{i} k\right]+\sum_{k \in Z} b_{I, k} h_{I}\left[n-2^{I} k\right]
$$

The DWT calculates the wavelet coefficients $a_{i, k}$ for $i=1, \ldots, I$ and the scaling coefficients $b_{i, k}$. The latter are given by

$$
D W T\left\{x[n] ; 2^{I}, k 2^{I}\right\}=a_{i, k}=\sum_{n} x[n] g_{i}^{*}\left[n-2^{i} k\right]
$$

and

$$
b_{I, k}=\sum_{n} x[n] h_{I}^{*}\left[n-2^{I} k\right],
$$

where $g_{i}\left[n-2^{i} k\right] \mathrm{s}$ are the discrete wavelets, and $h_{I}\left[n-2^{I} k\right]$ s are the scaling sequences [25].

A basic wavelet function to be compared with the signal should be chosen. There are many different functions suitable as wavelet, each one having different characteristics. One hundred ten wavelets consisting of different orders of Daubechies, Coiflets, Symlets, discrete Meyer, biorthogonal, and reverse biorthogoanl wavelets were compared by Cong et al. [20]. Finally, the Reverse biorthogonal wavelet with an order of 6.8 was chosen for wavelet decomposition of MMN. The Spline wavelet was used to study the P300 of young people by Demiralp et al. [26]. Ademoglu et al. also used quadratic spline wavelet to characterize the N70-P100-N130 EP complex [27].

Four data processing methods, DW, DF, and WLD with two different-type wavelet methods were used for comparison of the results. The MMN response is typically obtained in frontocentral sites better than in others [28]; so, the following processes were applied in site FCz. In each method, MMN properties (peak amplitude and latency) were extracted.

For DW, traces were calculated by subtracting the responses to the standard stimuli from each type of deviants. The peak amplitude and latency were calculated in $\mathrm{FCz}$ for each subject. These properties were obtained based on the highest negativity of averaged MMN within a time window of 100-230 msec post-stimulus.

The DF was applied in three steps. Fourier transform of the signals was performed on average traces; then, Fourier confidents outside the $1-8 \mathrm{~Hz}$ range were set to zero, and, finally, inverse Fourier transform was used to obtain the filtered traces.

For WLD, two different wavelets were used to decompose the signal into seven levels, and approximation coefficients of the sixth level were selected for reconstruction. Filter coefficients corresponding to quadratic B-Spline wavelet were computed as was described by Ademoglu et al. [27]. Filter coefficients for Reverse biorthogonal were obtained by MATLAB. WLD with quadratic B-Spline wavelet is denoted below as WLD-BS, and WLD by Reverse biorthogonal with an order of 6.8 is denoted as WLD-RB.

In WLD, if the number of the decomposition levels is $L$, the number of samples of the signal per one second is $N$ under conditions of $N=2^{L}[6]$.

In our study, the sampling frequency for EEG data recording was set to $1024 \mathrm{sec}^{-1}$, so, the signal 
could be composed of ten levels. The bandwidths at each decomposition level are shown in Table 1. The frequencies are estimates of the bandwidth of each level, and these frequencies are not related to the properties of any wavelet.

Because the off-line digital band-pass filter was applied in $0.5-40 \mathrm{~Hz}$, there is no useful data within the frequency band for D1 to D4. For WLD, the data were decomposed into seven levels. As is indicated in Table 1, the frequency range for A6 matched best the optimum frequency range of MMN. This frequency band corresponds to a delta-theta range of EEG signals.

The DW, DF, and wavelet filters have the linear additive property. Hence, first averaged traces were calculated; then WLD and DF were applied to reduce the computation loading.

\section{RESULTS}

Analysis of the efficacy of main effect of MMN measurements based on different methods was the main purpose of our study. The first MMN peak amplitude and latency were detected in each MMN for each subject, and then these data were examined using repeated-measures analysis of variance (ANOVA) to determine whether a difference of MMN properties (peak amplitude and latency) between five deviants was evident under each method used, respectively. Also, we wanted to determine whether the differences of MMN properties between WLD-BS and the DW, DF, or WLD-RB are significant.

Figure 4 shows grand averaged waveforms obtained using DW, DF, and WLD procedures for each type of MMN. The thick solid, thin solid, dashed, and dotted
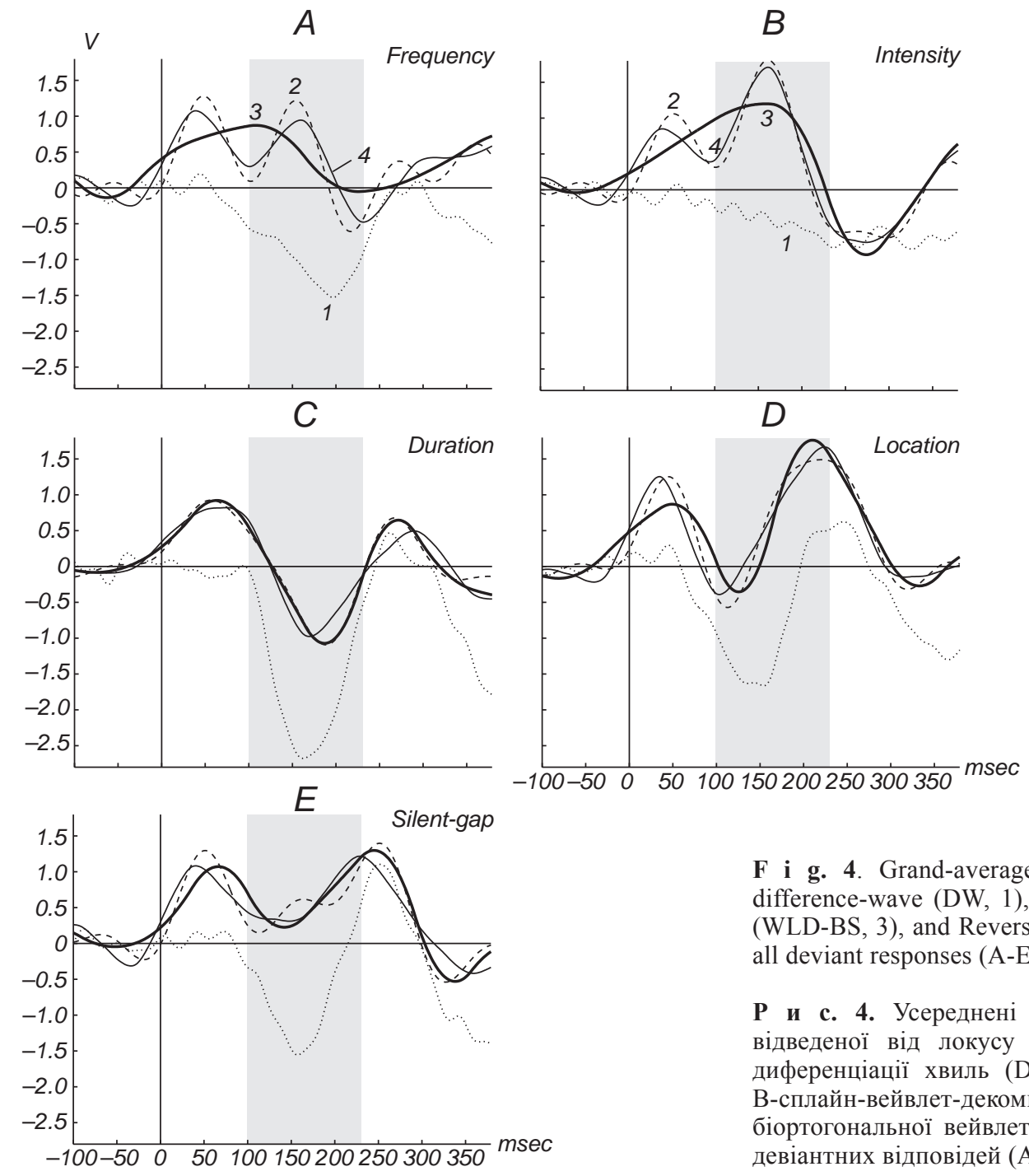

F i g. 4. Grand-averaged traces recorded from site $\mathrm{FCz}$ for difference-wave (DW, 1), digital filter (DF, 2), B-Spline wavelet (WLD-BS, 3), and Reverse biorthogonal wavelet (WLD-RB, 4) of all deviant responses (A-E).

P и с. 4. Усереднені записи негативності розузгодження, відведеної від локусу $\mathrm{FCz}$ та виділеної 3 використанням диференціації хвиль (DW, 1), цифрової фільтрації (DF, 2), B-сплайн-вейвлет-декомпозиції (WLD-BS, 3) та зворотної біортогональної вейвлет-декомпозиції (WLD-RB, 4), для всіх девіантних відповідей (А-Е). 


\section{T a b l e 1. Frequency Levels for Wavelet Decomposition}

T а б л и ц я 1. Частотні рівні для вейвлет-декомпозиції

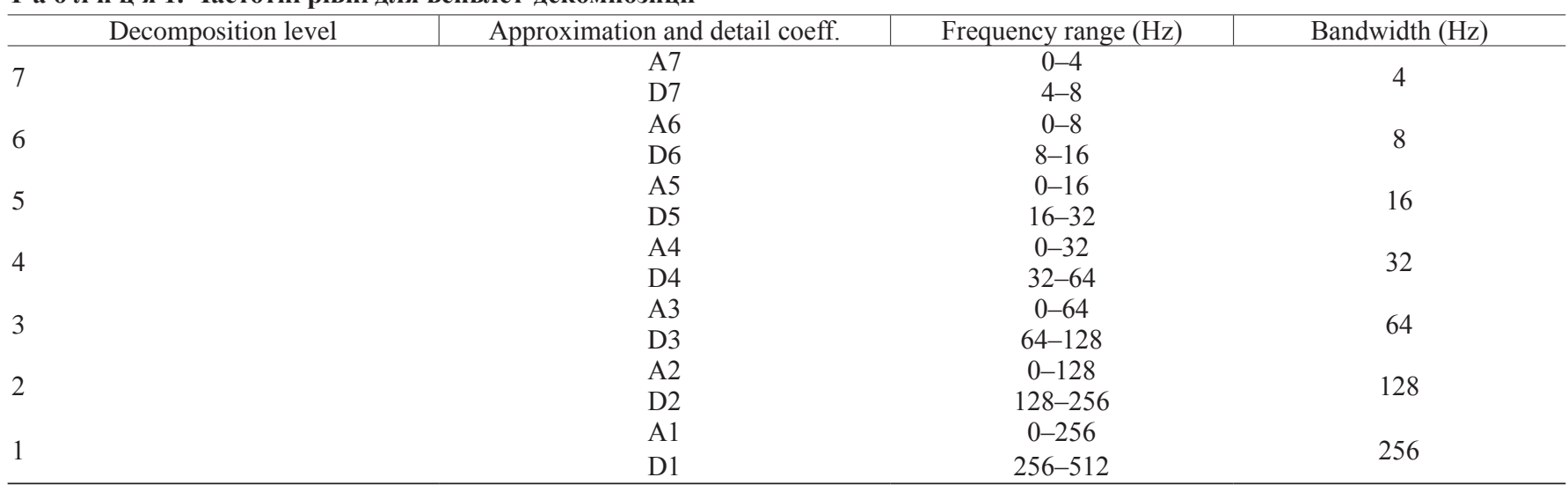

lines represent the WLD-BS, WLD-RB, DF, and DW traces, respectively. A gray field designates the time window where the MMN peak amplitude was detected. As is shown, MMN did not appear for the intensity deviant in a same wave as some other researchers reported [29]; this is why we excluded it from the subsequent analysis.

The MMN peak latencies detected by different methods were found to be very similar $\left(F_{4.42}=0.96\right.$, $P=0.41$ ), although this was not true for the MMN peak amplitudes $\left(F_{4,42}=38.02, P<0.000\right)$. The peak amplitudes obtained by DW differed considerably from those obtained by WLDs or DF.

To investigate which MMN extraction method is better, the abilities of these methods to discriminate between different MMN types were compared. Hence, the MMN properties (peak latency and amplitude) extracted by the above processing methods were examined in all combinations.

The results of MMN extraction between each type of deviants using different methods are shown in Fig. 5. All statistical tests of the differences between the MMN peak amplitudes and latencies elicited by four deviants using four methods are collected in this Figure. Two horizontal lines indicate 0.05 and 0.01 borders for the $P$ value to determine whether a result is statistically significant. For all methods, the differences of the peak magnitude or latency between location and silent-gap deviants were not significant. The peak latency differences between frequency and duration deviants were also not significant for all methods, and the difference of the peak amplitude between these two deviants was significant for DW. Main effects of all methods for the peak latency in all combinations of deviants were similar to each other, as
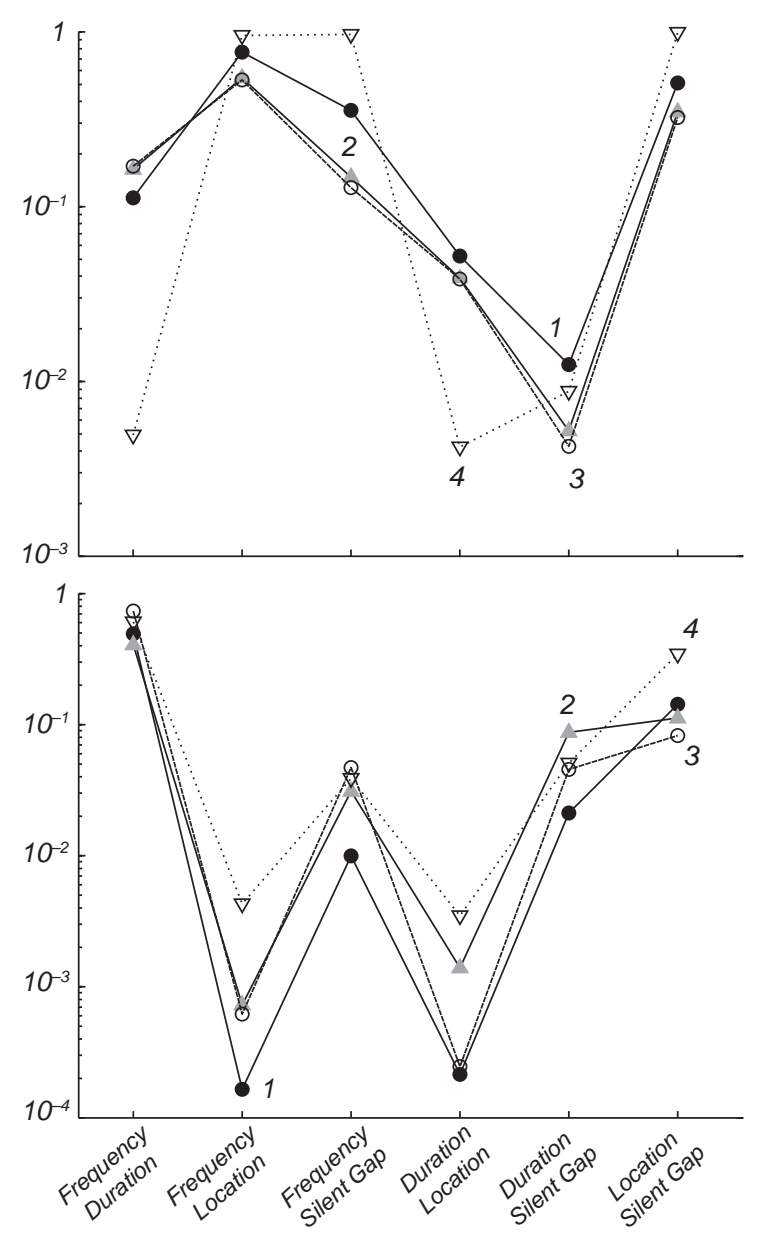

F i g. 5. Statistical tests of the differences between four types of the MMN amplitude and latency extracted by WLD-BS (1), WLD-RB (2), DF (3), and DW (4).

Р и с. 5. Статистичні тести щодо різниць між негативностями розузгодження за амплітудою $(A)$ та латентним періодом $(B)$, виділених з використанням WLD-BS (1), WLD-RB (2), DF (3) та DW (4). 


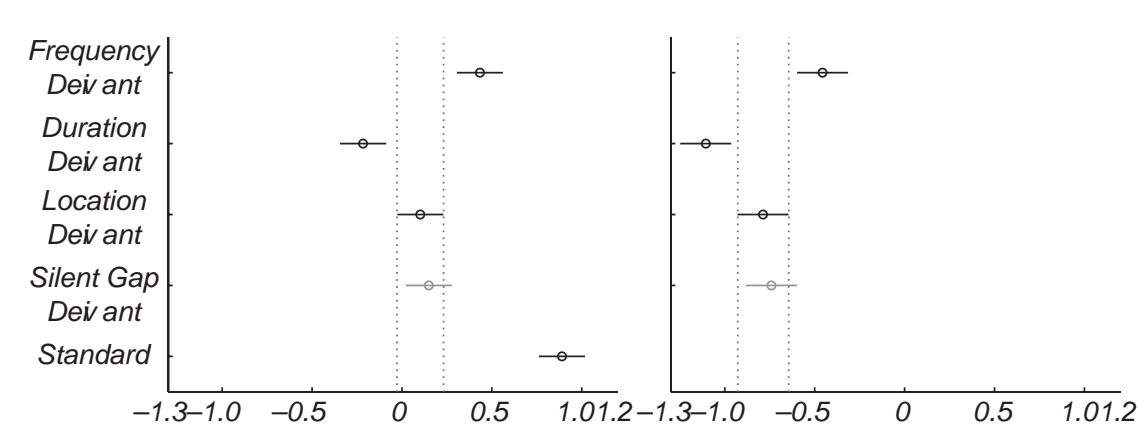

F i g. 6. Comparison tests (with Bonferroni adjustment) between MMN delta-theta-range coefficients extracted by WLD-BS and WLDRB. The WLD coefficients for averaged deviant responses and standards are shown in column A); WLD coefficients for difference waves are shown in column B.

P и с. 6. Тести порівняння (з наближенням Бонферроні) між дельта-тета-коефіцієнтами негативності розузгодження, виділеними 3 використанням WLD-BS та WLD-RB.

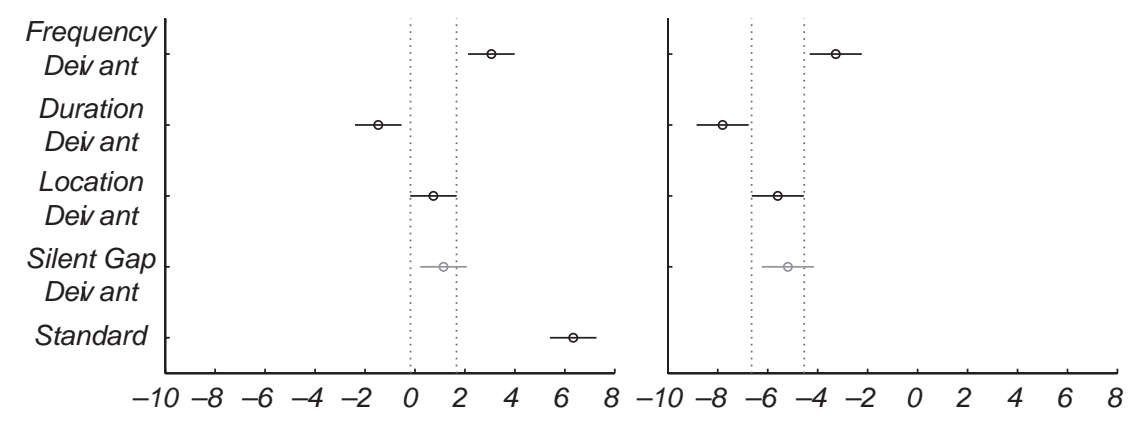

it was expected from averaged traces in Fig. 4. Totally, the peak latency in WLD-BS for all combinations of deviants was significantly greater than that in other methods.

In wavelet-based MMN extraction methods, coefficients of various decomposition levels consist of time-frequency information, in contrast to DW or DF that only have data of either time or frequency domains. According to the frequency band for MMN (about 1 to $10 \mathrm{~Hz}$ ), the coefficients of sixthlevel decomposition were compared together. Figure 6 shows statistical comparison of the test results of different types of responses for WLD methods. The WLD coefficients of averaged traces were compared by WLD-BS and WLD-RB; in column A, this is performed for standard and four deviants and in column B, this is performed for different waves. As it shown, discriminations are similar to each other and independent of the standard, i.e., whether a standard sweep was subtracted from the deviant sweeps or not. It should be noted that critical values from the $t$ distribution were used after Bonferroni adjustment, to compensate multiple comparisons.

The WLD coefficients of delta-theta range for the standards were significantly greater than those for the deviants. There are main effects with respect to the deviant pairs, frequency/location, frequency/silent gap, duration/location, and duration/silent gap. These results are obvious in Fig .5 if the latency was the comparison factor. There was no main effect between the location and silent-gap deviants for each method, either for the peak latency and amplitude, or for the WLD coefficients.

\section{DISCUSSION}

In our study, the criteria used for evaluating the performance of the data processing methods were based on the MMN properties, i.e., it was believed that different types elicit different MMNs [30]. The experiment included five deviants differing in the frequency, intensity, duration, perceived location, and silent gap. The WLDs gave the actual MMN peak magnitude and latency, as was confirmed by analyzing the MMN properties between deviants (see Fig. 5).

Table 2 shows statistical test results on the MMN peak amplitude and latency between WLD-BS and the DF, DW, or WLD-RB. For ANOVA, the method was the factor. The respective results show that the proposed WLD-BS performed differently with the DW in extracting MMN. However, there is a main effect between these two methods in extracting the MMN peak amplitude; they provided similar discriminations between different deviants (see Fig. 5).

WLD can be regarded as a special bandpass filter. The frequency responses of quadratic B-Spline WLD and Reverse biorthogonal WLD with the order of 6.8 are shown in Fig. 7, and their filter coefficients are shown in Fig. 8. The wavelet morphologies are similar, while the frequency responses are different. Reverse boirthogonal 6.8 is alike to be an ideal bandpass 
Table 2. Statistical Tests of the Differences Between WLD-BS and Other Methods in the Analysis of the Peak Amplitude and Latency

T а б л и ц я 2. Статистичні тести щодо різниць між WLD-BS та іншими методами при аналізі пікових амплітуд та латентних періодів

\begin{tabular}{l|c|c|c|c}
\hline \multirow{2}{*}{ Parameter } & \multirow{2}{*}{ Value } & \multicolumn{3}{c}{ Methods } \\
\cline { 3 - 5 } Amplitude & & WLD-BS vs DW & WLD-BS vs DF & WLD-BS vs WLD-RB \\
\cline { 3 - 5 } Latency & $\mathrm{F}(1,42)$ & 83.79 & 3.85 & 0.83 \\
& $P$ & $<0.0000$ & 0.0504 & 0.3621 \\
& $\mathrm{~F}(1,42)$ & 3.64 & 0.43 & 0.52 \\
\hline
\end{tabular}

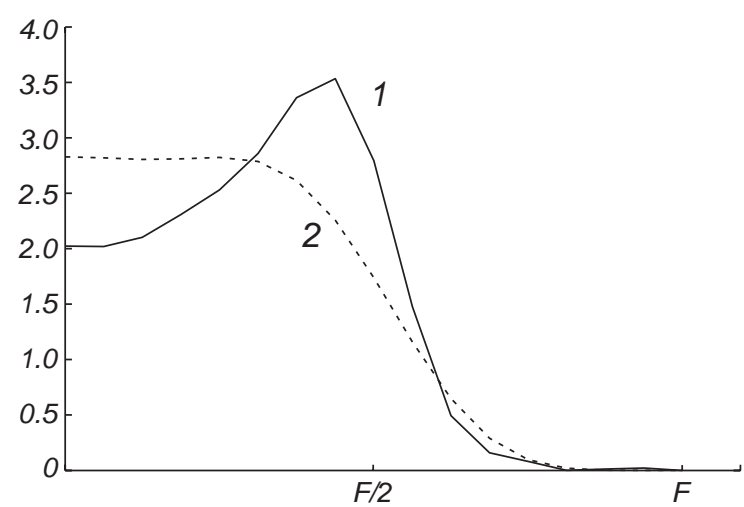

F i g. 7. Frequency characteristics of the wavelet filters (1 and 2, for B-Spline and Reverse biorthogonal 6.8, respectively).

P и с. 7. Частотні характеристики вейвлет-фільтрів (1 - для В-сплайнового, 2 - для зворотного біортогонального).

filter in contrast to quadratic B-Spline that amplifies frequencies close to the cut-off frequency.

Considering frequency information of MMN, we need the filter having a better frequency match with the $\mathrm{MMN}$ frequency range to extract pure MMN. It seems that the WLD-BS is a good method for extracting MMN with better properties.

In our study, the compared results showed that there is no disparity between the WLD coefficients of deviants and WLD coefficients of DW (see Fig. 6). Hence, we can apply WLD to deviants directly instead of DW.

The WLD approach was applied for investigation of the differences between types of MMN obtained by the multi-feature paradigm in a sampling of normally hearing people. From this point of view, the WLD method and WLD coefficients can be used with respect to other subjects, e.g., complainers of hearing disorders; these also can be used to specify some brain pathologies.

Ideally, only MMN activity should remain in the data for detecting properties or feature extraction after

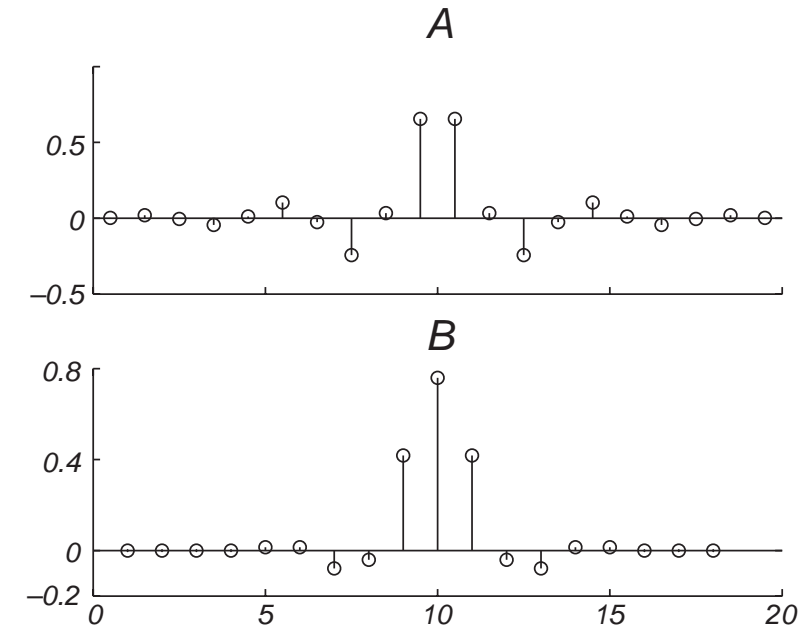

F i g. 8. Filter coefficients for quadratic B-Spline wavelet (A) and Reverse biorthogonal 6.8 wavelet (B).

Р и с. 8. Коефіцієнти фільтрації для квадратичного В-сплайнвейлвета $(A)$ та зворотного біортогонального 6.8 вейлвета $(B)$.

data processing. However, the DW only removes the common variance in standard and deviants traces; other types of activity that overlap MMN are not segregated just in the time or frequency domain. Thus, time-frequency processing can be used to obtain pure MMNs; time and frequency information should be applied together for analyzing. This matter motivated us to use time-frequency analyzing based on WLD and to compare types of MMN elicited by the specified new paradigm. With this approach, we have found that the WLD coefficients are better tools to compare MMNs than estimation of traditional MMN properties (peak latency and amplitude).

The Ethics Committee of ENT and Head and Neck Research Center, Tehran University of Medical Sciences, acknowledged the study design (code number: MT.8829/90-12-25) as corresponding to the internationally accepted ethic standards. All participants of the tests were informed in detail on the 
experimental procedure and gave their written consent.

The authors, M. Najafi-Koopaie, H. Sadjedi, S. Mahmoudian, E. D. Farahani, and M. Mohebbi, confirm that they have no conflict of interest.

M. Наджафі-Купайє ${ }^{1}$, X. Саджеді ${ }^{1}$, C. Махмудіан ${ }^{2,3}$, Е. Д. Фарахані ${ }^{4}$, М. Мохеббі

ЕЕГ-НЕГАТИВНІСТЬ РОЗУЗГОДЖЕННЯ, ЗАРЕССТРОВАНА В УМОВАХ МНОЖИННОЇ ПАРАДИГМИ: АНАЛІЗ, ЗАСНОВАНИЙ НА ВЕЙВЛЕТДЕКОМПОЗИЦІї

\author{
1 Університет Шахед, Тегеран (Іран). \\ ${ }^{2}$ Ганноверський медичний університет (ФРН). \\ ${ }^{3}$ Тегеранський університет медичних наук (Іран). \\ ${ }^{4}$ Технологічний університет Аміркабір, Тегеран (Іран). \\ P е $з$ ю м е
}

У суб'єктів із нормальним слухом реєстрували пов'язані 3 подією потенціали, викликані з використанням множинної парадигми. Стандартні слухові стимули та девіантні стимули п'яти типів пред'являли в специфічній послідовності; ЕЕГ-потенціали відводили з частотою дискретизації $1024 \mathrm{c}^{-1}$. Результати двох видів вейвлет-аналізу порівнювали 3 даними, отриманими із застосуванням традиційного методу диференціації хвиль (DW). Зворотний біортогональний вейвлет порядку 6.8 і квадратичний В-сплайновий вейвлет використовували для декомпозиції сьомого порядку. Коефіцієнти наближення шостого порядку виявилися застосовними для виділення негативності розузгодження (MMN) iз усереднених записів. Як показали результати, методи вейвлет-декомпозиції (WLD) дозволяють виділити негативність розузгодження так само успішно, як і цифрові фільтри. Відмінності латентних періодів піків негативності розузгодження для девіантних варіантів стимуляції, виявлені в разі застосування В-сплайнової WLD, були більш вірогідними, ніж аналогічні відмінності при використанні методу диференціації хвиль, цифрової фільтрації або зворотної біортогональної WLD. Вейвлет-коефіцієнти для дельта-тета-діапазону також дозволяли отримати найкращу дискримінацію деяких комбінацій девіантних типів.

\section{REFERENCES}

1. R. Näätänen, A. W. K. Gillard, and S. Mäntysalo, "Early selective-attention effect on evoked potential reinterpreted," Acta Psychol. (Amst.), 42, 313-329 (1978).

2. R. Näätänen and I. Winkler, "The concept of auditory stimulus representation in cognitive neuroscience," Psychol. Bull., 125, 826-859 (1999).
3. R. Näätänen, P. Paavilainen, T. Rinne, and K. Alho, “The mismatch negativity (MMN) in basic research of central auditory processing: A review," Clin. Neurophysiol., 118, 2544-2590 (2007).

4. R. Näätänen, S. Pakarinen, T. Rinne, and R. Takegata, "The mismatch negativity (MMN): towards the optimal paradigm," Clin. Neurophysiol., 115, 140-144 (2004).

5. R. Näätänen, Attention and Brain Functions, Hillsdale, New Jersey (1992).

6. J. Sinkkonen and M. Tervaniemi, "Towards optimal recording and analysis of the mismatch negativity," Audiol. Neurootol., 5, 235-246 (2000).

7. G. Stefanics, G. Haden, L. Balazs, et al., "Auditory temporal grouping in newborn infants," Psychophysiology, 44, 697-702 (2007).

8. M. Burgur, U. Hoppe, P. Kummer, et al., "Wavelet-based analysis of MMN responses in children," Biomed. Technol., 52, 11-116 (2007).

9. F. Cong, I. Kalyakin, H. Li, et al., "Answering six questions in extracting children's mismatch negativity through combining wavelet decomposition and independent component analysis," Cogn. Neurodyn., 5, 343-359 (2011).

10. J. Dien, "The ERP PCA toolkit: an open source program for advanced statistical analysis of event related potential data," J. Neurosci. Methods, 187, 138-145 (2010).

11. F. Cong, I. Kalyakin, A. Phan, et al., "Identical fits of nonnegative matrix/tensor factorization may correspond to different extracted event-related potentials," Proc. Int. Jt. Conf. Neural Netw., 2260-2264 (2010).

12. S. Orfanadis, F. Afif, and E. Micheli-Tzanakou, "Visual evoked potentials extraction by adaptive filtering," Conf. Proc. IEEE Eng. Med. Biol. Soc., 968-969 (1987).

13. N. Thakor, "Adapting filtering of evoked potentials," IEEE Trans. Biomed. Eng., BME-33, 1085-1095 (1987).

14. E. Hamzaoui, F. Regragui, M. M. Himmi, and A. Mghari, "Visual evoked potentials' non linear adaptive filtering based on three layers perceptron," Appl. Math. Sci. (Ruse), 4, 27592772 (2010).

15. P. Laguna, R. Jane, O. Meste, et al., "Adaptive filter for event-related bioelectric signals using an impulse correlated reference input," IEEE Trans. Biomed. Eng., 39, 1032-1044 (1992).

16. C. A. Vaz and N. V. Thakor, "Adaptive Fourier estimation of time-varying evoked potentials," IEEE Trans. Biomed. Eng., 36, 448-455 (1989).

17. N. V. Thakor, Y. Sun, H. Rix, and P. Caminal, "Multiwave: a wavelet-based ECG data compression algorithm," IEICE Trans. Inf. Syst., E-76D, 1462-1469 (1993).

18. S. J. Schif, A. Aldroubi, M. Unser, and S. Sato, "Fast wavelet transformation of EEG," Electroencephalogr. Clin. Neurophysiol., 91, 442-455 (1994).

19. V. J. Samar, K.P. Swartz, and M.R. Raghuveer, "Multiresolution analysis of event-related potentials by wavelet decomposition," Brain Cogn., 27, 398-438 (1995).

20. F. Cong, Y. Huang, I. Kalyakin, et al., "Frequency-responsebased wavelet decomposition for extracting children's mismatch negativity elicited by uninterrupted sound," Med. Biol. Eng., 32, 205-214 (2012).

21. I. Kalyakin, N. Gonzalez, J.Joutsensalo, et al., "Optimal digital filtering versus difference wave on the mismatch negativity in an interrupted sound paradigm," Dev. Neuropsychol., 31, 429452 (2007). 
22. T. Picton, C. Alain, L. Otten, et al., "Mismatch negativity: different water in the same river," Audiol. Neurootol., 5, 111139 (2000).

23. M. Tervaniemi, A. Lehtokoski, J. Sinkkonen, et al., "Test-retest reliability of mismatch negativity for duration, frequency and intensity changes," Clin. Neurophysiol., 110, 1388-1393 (1999).

24. A. Grossman and J. Morlet, "Decomposition of hardy functions into square integrable wavelets of constant shape," SIAM J. Math. Anal., 15, 723-736 (1984).

25. S. Mallat, "A theory for multiresolution signal decomposition: the wavelet representation," IEEE Trans. Pattern. Anal. Mach. Intell., 11, 674-693 (1989).

26. T. Demiralp, Y. Istefanopulos, A. Ademoglu, et al., "Analysis of functional components of P300 by wavelet transform," Conf. Proc. IEEE Eng. Med. Biol. Soc., 20, 1992-1995 (1998).
27. A. Ademoglu, E. Micheli-Tzanakou, and Y. Istefanopulos, "Analysis of pattern reversal visual evoked potential (PRVEP's) by spline wavelet," IEEE Trans. Biomed. Eng., 44, 881-889 (1997).

28. T. Kujala, M. Tervaniemi, and E. Schröger, "The mismatch negativity in cognitive and clinical neuroscience: Theoretical and methodological considerations," Biol. Psychol., 74, 1-19 (2007).

29. H. Thönnessen, M. Zvyagintsev, K. C. Harke, et al., "Optimized mismatch negativity paradigm reflects deficits in schizophrenia patients a combined EEG and MEG study," Biol. Psychol., 77, 205-216 (2008).

30. R. Näätänen, S. Pakarinen, T. Rinne, and R. Takegata, "The mismatch negativity (MMN): towards the optimal paradigm," Clin. Neurophysiol., 115, 140-144 (2004). 